\title{
Green Synthesis of a Functionalized Zirconium-Based Metal-Organic Framework for Water and Ethanol Adsorption
}

\author{
Zhijie Chen ${ }^{1,+} \mathbb{C}$, Xingjie Wang ${ }^{1,2,+} \mathbb{C}$, Timur Islamoglu $1, * \mathbb{C}$ and Omar K. Farha ${ }^{1, *}$ \\ 1 Department of Chemistry and International Institute of Nanotechnology, Northwestern University, \\ 2145 Sheridan Road, Evanston, IL 60208, USA; zhijie.chen@northwestern.edu (Z.C.); \\ xingjie.wang@northwestern.edu (X.W.) \\ 2 School of Chemistry and Chemical Engineering, South China University of Technology, Guangzhou 510640, \\ China \\ * Correspondence: timur.islamoglu@northwestern.edu (T.I.); o-farha@northwestern.edu (O.K.F.) \\ + These authors contributed equally to this work.
}

Received: 8 April 2019; Accepted: 21 April 2019; Published: 26 April 2019

check for updates

\begin{abstract}
Aqueous synthesis of metal-organic frameworks (MOFs) at room temperature offers many advantages such as reduction in the generation of toxic byproducts and operation costs, as well as increased safety in the material's production. Functional group-bearing MOFs have received growing attention compared to nonfunctionalized analogues due to enhanced adsorption properties of the former in many cases. Here, we report an aqueous solution-based synthesis of a robust zirconium MOF, $\mathrm{UiO}-66-\mathrm{NO}_{2}$, at room temperature. We evaluated the phase purity, porosity, thermal stability, particle morphology and size of the resulting material. High uptake, as well as near complete recyclability of water and ethanol vapor isotherms at room temperature supports the potential of $\mathrm{UiO}-66-\mathrm{NO}_{2}$ as a solid adsorbent in adsorption-based cooling applications or water harvesting systems.
\end{abstract}

Keywords: zirconium-based MOFs; water adsorption; ethanol adsorption; porous materials; adsorption heat pump

\section{Introduction}

Metal-organic frameworks (MOFs) [1-5] are a promising class of crystalline porous materials with a wide range of applications including but not limited to heterogeneous catalysis [6-10], enzyme and nanoparticle encapsulation [11-14], water capture [15-19], gas storage, and separation [20-25]. Importantly, physical and chemical properties of MOFs can be fine-tuned with the help of reticular chemistry, where pre-selected molecular building blocks are combined to yield pre-designed frameworks for targeted applications [26-30].

While gas adsorption is the most widely studied application of MOFs, vapor adsorption in MOFs has recently garnered some attention especially with the increasing number of water-stable MOFs reported [15-19,31-33]. MOFs with a high capacity for water uptake at room temperature have also gained increasing attention. By tuning features such as the topology, pore size, pore volume, and chemical functionality of MOFs, the relative pressure where the water uptake reaches maximum can be controlled. This is essential for many applications such as natural gas dehydration [34], water capture from air [16,35], adsorption-based cooling systems [15,19,36], and indoor humidity cooling systems [18]. Ethanol can be also used as refrigerant for adsorption-driven cooling application due to its lower freezing point compared to water [37]. Nevertheless, all of these adsorption-based applications such as adsorption beds [21,38], mixed-matrix membranes [39,40], or devices for capturing water from 
air [35,41], require large amounts of adsorbents for operation. Consequently, developing green and scalable methods for synthesis of MOFs is of interest for the aforementioned applications.

We have recently reported a promising strategy for the scalable synthesis of $\mathrm{UiO}-66$ ( $\mathrm{UiO}=$ University of Oslo) analogues (i.e., UiO-66-(COOH $)_{2}$ and $\left.\mathrm{UiO}-66-\mathrm{F}_{4}\right)$ for toxic chemical removal [42]. Herein, we extended this method to the synthesis of a highly stable $\mathrm{Zr} \mathrm{MOF}, \mathrm{UiO}-66-\mathrm{NO}_{2}$ [43-45]. Various characterization techniques were implemented to confirm phase purity, morphology, thermal stability, and porosity of the resulting MOF. Moreover, we studied water and ethanol vapor adsorption of $\mathrm{UiO}-66-\mathrm{NO}_{2}$, which showed high uptake as well as good recyclability.

\section{Results and Discussion}

UiO-66 is constructed from 12-connected hexanuclear zirconium oxo-clusters and terephthalate linkers with face-centered cubic (fcu) topology [46]. Due to the exceptional chemical and thermal stability, UiO-66 has become one of the most studied MOFs since its invention in 2008 [43,46-49]. UiO-66 can be easily functionalized with different functional groups on account of its isoreticular chemistry [5], however, a vast majority of these studies involve $N, N$-dimethylformamide (DMF), a toxic organic solvent, and elevated temperatures [5]. We recently reported an inexpensive, scalable, and environmentally benign procedure to synthesize UiO-66 derivatives (UiO-66- $(\mathrm{COOH})_{2}$ and $\left.\mathrm{UiO}-66-\mathrm{F}_{4}\right)$ in water at room temperature [42]. Building on the previous successful examples, we extended our strategy to synthesize another $\mathrm{UiO}-66$ derivative, $\mathrm{UiO}-66-\mathrm{NO}_{2}$ (Figure 1A). Among those functionalized UiO-66 analogues, $\mathrm{UiO}-66-\mathrm{NO}_{2}$ is believed to be one of the most chemically stable $\mathrm{Zr}$ MOFs which makes it a potential candidate for broader applications [50,51].
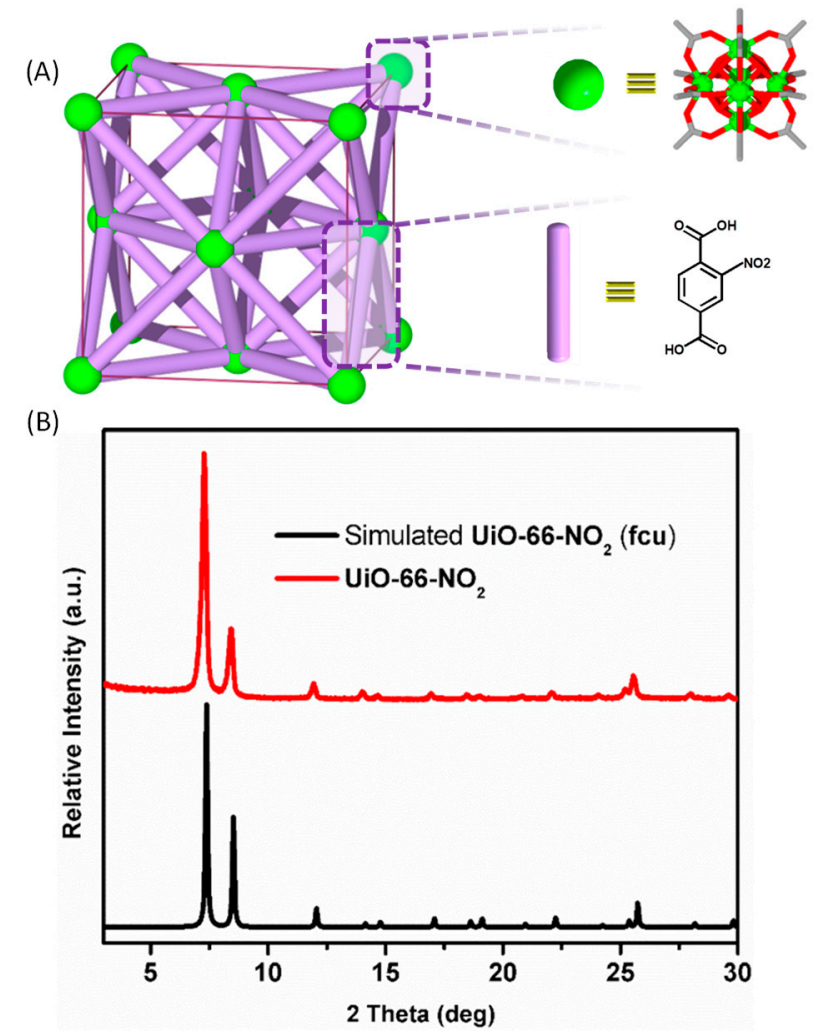

Figure 1. (A) Structural representation of $\mathrm{UiO}-66-\mathrm{NO}_{2}$ constructed from 12-c $\mathrm{Zr}$ nodes and linear 2-nitroterephthalic acid $\left(\mathrm{H}_{2} \mathrm{BDC}-\mathrm{NO}_{2}\right)$ ligand. (B) Powder X-ray diffraction (PXRD) pattern of the as-synthesized sample matched well with the simulated $\mathrm{UiO}-66-\mathrm{NO}_{2}$. 
As illustrated in Figure 1B, our aqueous synthetic method at room temperature resulted in phase-pure UiO-66- $\mathrm{NO}_{2}$ confirmed by the powder X-ray diffraction (PXRD) pattern. The crystal size of UiO-66- $\mathrm{NO}_{2}$ was about $100 \mathrm{~nm}$ as shown in the scanning electron microscopy (SEM) image (Figure S1).

$\mathrm{N}_{2}$ adsorption-desorption isotherms at $77 \mathrm{~K}$ revealed the experimental total pore volume at $P / P_{0}=0.8$ was about $0.43 \mathrm{~cm}^{3} \cdot \mathrm{g}^{-1}$, and the apparent Brunauer-Emmett-Teller (BET) area of UiO-66- $\mathrm{NO}_{2}$ was calculated to be $840 \mathrm{~m}^{2} \cdot \mathrm{g}^{-1}$ based on the relative pressure range from $P / P_{0}=0.004$ to $P / P_{0}=0.0294$ (Figure 2A), in line with the surface areas obtained from solvothermal synthesis [52]. The pore-size distribution based on non-local density functional theory (NLDFT) model with the cylindrical kernel showed two major pores. The main peak centered at about $1.3 \mathrm{~nm}$ was assigned to octahedral cages of ideal UiO-66 structure, and the smaller shoulder near $1.8 \mathrm{~nm}$ was assigned to the presence of non-ordered missing cluster defects (Figure 2B) [53]. The sharp increase in the $\mathrm{N}_{2}$ isotherm near saturation pressure was due to the condensation of the $\mathrm{N}_{2}$ gas at interparticle voids, which is common in MOFs with nanosized crystallites [54].

(A)

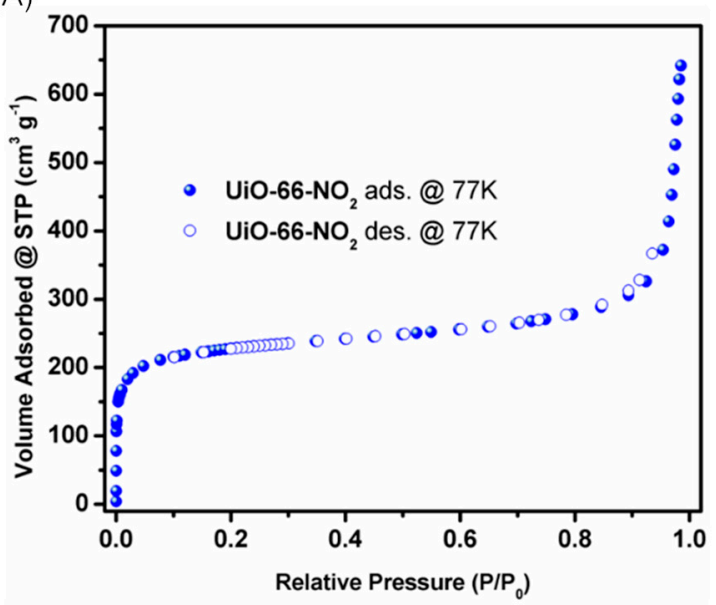

(B)

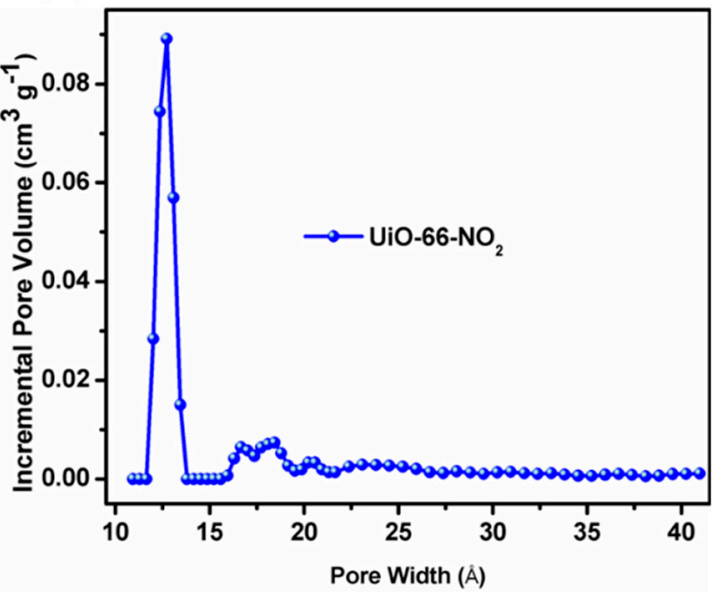

Figure 2. (A) $\mathrm{N}_{2}$ sorption isotherms of $\mathrm{UiO}-66-\mathrm{NO}_{2}$ at $77 \mathrm{~K}$ and (B) pore-size distribution based on a non-local density functional theory (NLDFT) model.

The thermogravimetric analyses (TGA) plot of UiO-66- $\mathrm{NO}_{2}$ under continuous air flow indicated that the framework was stable up to about $300{ }^{\circ} \mathrm{C}$ (Figure S2). The number of the linkers per $\mathrm{Zr}_{6}$ node inside UiO-66- $\mathrm{NO}_{2}$ was estimated to be about 4.3 according to the TGA plot, assuming the full combustion of MOFs under the air flow. This indicated the defective nature of this UiO-66- $\mathrm{NO}_{2}$ synthesized in water at room temperature, which was consistent with the pore size distribution, further indicating the presence of defects. Diffuse reflectance infrared Fourier transform spectroscopy (DRIFTS) spectra was collected on this material where a sharp band at $3667 \mathrm{~cm}^{-1}$ was assigned to $\mu_{3}$ -OH stretches on the hexanuclear zirconium oxo-clusters (Figure S3) which was red-shifted compared to its parent UiO-66 [55] and consistent with solvothermally synthesized $\mathrm{UiO}-66-\mathrm{NO}_{2}$ [52]

Encouraged by the moderate surface area and high stability of the UiO-66- $\mathrm{NO}_{2}$, we further studied the ethanol and water vapor sorption, which is important for practical applications such as adsorption-based heat pump and vapor capture from air, respectively. Ethanol adsorption of UiO-66- $\mathrm{NO}_{2}$ at $298 \mathrm{~K}$ showed an uptake of about $112 \mathrm{~cm}^{3} \cdot \mathrm{g}^{-1}$ at $P / P_{0}=0.3$ and about $186 \mathrm{~cm}^{3} \cdot \mathrm{g}^{-1}$ at $P / P_{0}=0.9$, respectively (Figure 3 ). Moreover, it retained its ethanol sorption performance for the second cycle after the simple activation under dynamic vacuum.

Water adsorption isotherm at room temperature is important to gauge MOFs for their potential for water vapor sorption related applications or to assess their moisture stability [19,35]. Thus, we performed the water vapor sorption at $298 \mathrm{~K}$ for $\mathrm{UiO}-66-\mathrm{NO}_{2}$, which exhibited an S-shape adsorption isotherm (Figure 4). The uptake of water vapor at $P / P_{0}=0.9$ was about $459 \mathrm{~cm}^{3} \cdot \mathrm{g}^{-1}$ (or $0.37 \mathrm{~g} \cdot \mathrm{g}^{-1}$ ), and this value was slightly smaller than the reported value [17] of parent UiO-66 $\left(533 \mathrm{~cm}^{3} \cdot \mathrm{g}^{-1}\right.$ or 
$\left.0.43 \mathrm{~g} \cdot \mathrm{g}^{-1}\right)$, due to the reduction of pore volume after the introduction of nitro-groups. On the other hand, the water uptake of UiO-66- $\mathrm{NO}_{2}$ at $P / P_{0}=0.3$ was about $177 \mathrm{~cm}^{3} \cdot \mathrm{g}^{-1}$ (or $0.14 \mathrm{~g} \cdot \mathrm{g}^{-1}$ ) which was higher than that of UiO-66 $\left(108 \mathrm{~cm}^{3} \cdot \mathrm{g}^{-1}\right.$ or $\left.0.09 \mathrm{~g} \cdot \mathrm{g}^{-1}\right)$, indicating the more hydrophilic nature of this material in comparison with the parent UiO-66. The second run of the same batch material also verified the good cycling ability and therefore the stability of $\mathrm{UiO}-66-\mathrm{NO}_{2}$. Note, the UiO-66- $\mathrm{NO}_{2}$ synthesized in aqueous solution at room temperature showed similar water uptake to that previously reported $\left(459 \mathrm{~cm}^{3} \cdot \mathrm{g}^{-1}\right.$ (or $20.5 \mathrm{mmol} \cdot \mathrm{g}^{-1}$ ) in this work, in comparison to $533 \mathrm{~cm}^{3} \cdot \mathrm{g}^{-1}$ (or $22 \mathrm{mmol} \cdot \mathrm{g}^{-1}$ ) at $P / P_{0}=0.9$ by Walton and coworkers [44]), further confirming the practicality of this synthesis method of UiO-66- $\mathrm{NO}_{2}$ compared to that of solvothermal based methods.

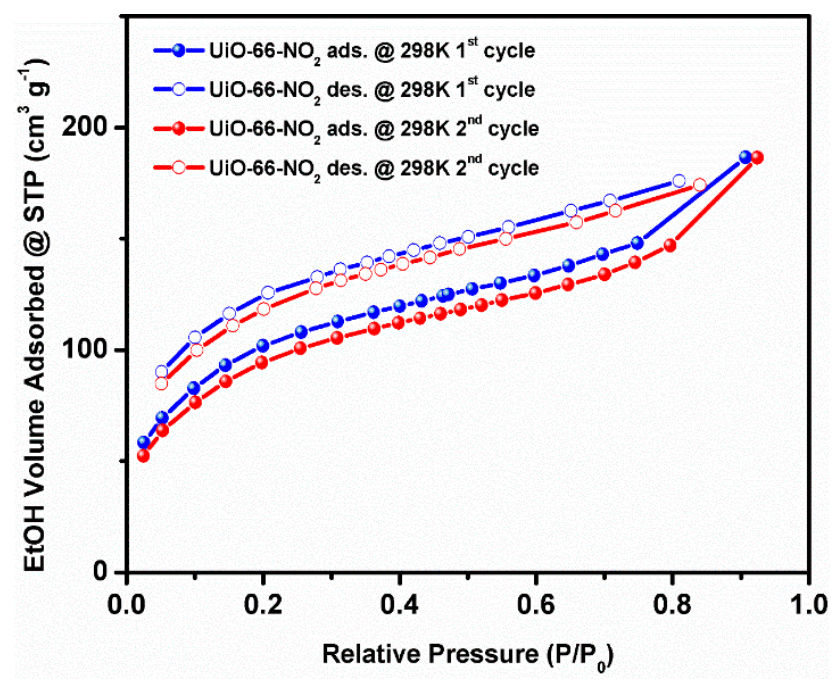

Figure 3. Ethanol sorption isotherms of $\mathrm{UiO}-66-\mathrm{NO}_{2}$ at $298 \mathrm{~K}$ (two cycles).

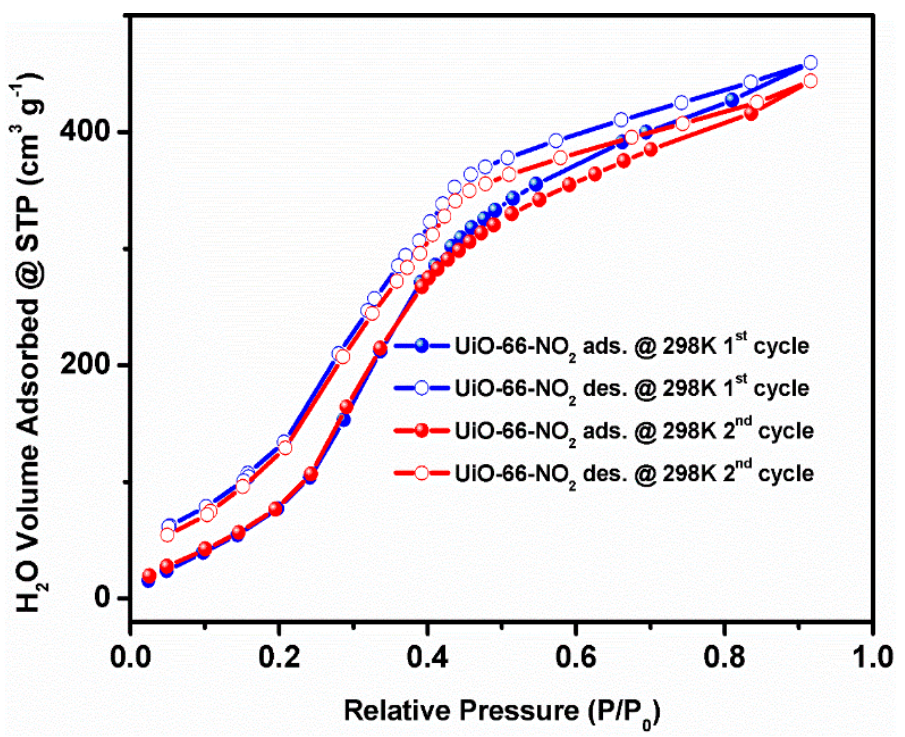

Figure 4. Water sorption isotherms of $\mathrm{UiO}-66-\mathrm{NO}_{2}$ at $298 \mathrm{~K}$ (two cycles).

\section{Materials and Methods}

All reagents were obtained from commercial sources and used without further purification, unless otherwise noted. Zirconium (IV) oxynitrate hydrate (99\%) was purchased from Sigma-Aldrich (St. Louis, MO, USA). 


\subsection{X-ray Diffraction Analyses}

Powder X-ray diffraction (PXRD) of MOFs were measured at room temperature on a STOE-STADIMP powder diffractometer (STOE \& Cie GmbH, Darmstadt, Germany) equipped with an asymmetric curved Germanium monochromator $(\mathrm{Cu} \mathrm{K} \alpha 1$ radiation, $\lambda=1.54056 \AA)$ and one-dimensional silicon strip detector (MYTHEN2 1K from DECTRIS, Baden, Switzerland). The line focused Cu X-ray tube was operated at $40 \mathrm{kV}$ and $40 \mathrm{~mA}$. The activated powder was sandwiched between two Kapton foils and measured in transmission geometry in a rotating holder. Intensity data from 1 to 30 degrees two theta were collected over a period of $6 \mathrm{~min}$. The instrument was calibrated against a NIST Silicon standard (640d) prior to the measurement.

\section{2. $\mathrm{N}_{2}$ Sorption Measurements}

$\mathrm{N}_{2}$ adsorption and desorption isotherms on activated materials were measured on a Tristar (Micromeritics, Norcross, GA, USA) instrument at $77 \mathrm{~K}$. In general, about 30-50 mg of sample was used in each measurement after activated at $120^{\circ} \mathrm{C}$ for $24 \mathrm{~h}$.

\subsection{Thermogravimetric Analyses (TGA)}

TGA was performed on a TGA/DCS 1 system (Mettler-Toledo AG, Schwerzenbach, Switzerland), which runs on a PC with STARe software. Samples were heated from 30 to $600{ }^{\circ} \mathrm{C}$ at a rate of $10{ }^{\circ} \mathrm{C} / \mathrm{min}$ under air with flow rate $20 \mathrm{~mL} / \mathrm{min}$.

\subsection{Diffuse Reflectance for Infrared Fourier Transform Spectroscopy (DRIFTS)}

DRIFTS spectra were recorded on a Nicolet 6700 FTIR spectrometer (Thermo Nicolet Corp., Madison, WI, USA) equipped with an MCT detector. The detector was cooled with liquid $\mathrm{N}_{2}$ and the spectra were collected under $\mathrm{Ar}$ atmosphere. $\mathrm{KBr}$ was utilized as a background spectrum.

\subsection{Scanning Electron Micrographs (SEM)}

Scanning electron micrographs (SEM) images were taken using a Hitachi SU8030 (Hitachi High Technologies Corporation, Tokyo, Japan) at the EPIC facility (NUANCE Center-Northwestern University). Samples were activated and coated with $\mathrm{OsO}_{4}$ to $\sim 9 \mathrm{~nm}$ thickness in a Denton Desk III TSC Sputter Coater before imaging.

\subsection{Water and Ethanol Vapor Sorption Measurements}

Water and ethanol isotherms were measured on a 3Flex (Micromeritics), and the water uptake in $\mathrm{g} \cdot \mathrm{g}^{-1}$ unit is calculated as [(adsorbed amount of water)/(amount of adsorbent)]. Prior to the adsorption measurements, water or ethanol (analyte) was flash frozen under liquid nitrogen and then evacuated under dynamic vacuum at least 3 times to remove any gases in the water reservoir until the $\mathrm{P} 0$ of the analyte gas matches the suggested $\mathrm{P} 0$ at room temperature. The measurement temperature was controlled with an ISO Controller (Micromeritics).

\subsection{Synthesis of $\mathrm{UiO}-66-\mathrm{NO}_{2}$}

$1.5 \mathrm{~mL}$ of water was added to $20 \mathrm{mg}(\sim 0.094 \mathrm{mmol})$ of 2-nitroterephthalic acid. The mixture was then placed in the oven at $100{ }^{\circ} \mathrm{C}$ for $5 \mathrm{~min}$. The color of the solution became pale yellow. Separately, $48 \mathrm{mg}(\sim 0.208 \mathrm{mmol})$ of zirconyl nitrate hydrate $\left(\mathrm{ZrO}\left(\mathrm{NO}_{3}\right)_{2} \cdot x \mathrm{H}_{2} \mathrm{O}\right)$ was dissolved by adding $1.0 \mathrm{~mL}$ of water followed by sonication. The two solutions were combined, followed by an addition of $300 \mu \mathrm{L}$ $(\sim 5.24 \mathrm{mmol})$ of acetic acid. The mixture was stirred for $72 \mathrm{~h}$ at room temperature. The crystalline powders were collected by centrifugation (7000 rpm for $30 \mathrm{~min}$ ). As-synthesized sample was washed 3 times with DI water and then sequentially washed 2 times with ethanol, and finally immersed in acetone for 2 days, during which time the acetone was replaced 2 times per day. The product was 
obtained after initial drying via leaving exposed to ambient atmosphere overnight and activated at $120{ }^{\circ} \mathrm{C}$ for $24 \mathrm{~h}$; yield: $25 \mathrm{mg}$.

\section{Conclusions}

In conclusion, we extended the room temperature, aqueous methodology of $\mathrm{Zr}$ MOFs to access a nitro-functionalized $\mathrm{UiO}-66$ derivative, $\mathrm{UiO}-66-\mathrm{NO}_{2}$. Importantly, the $\mathrm{UiO}-66-\mathrm{NO}_{2}$ obtained here, using more environmentally benign methods, showed comparable BET area to MOFs obtained from solvothermal synthesis. Moreover, water and ethanol vapor sorption isotherms at room temperature indicated high uptake of both vapors, which suggests potential of $\mathrm{UiO}-66-\mathrm{NO}_{2}$ for adsorption-based cooling applications or water harvesting systems.

Supplementary Materials: The following are available online at http://www.mdpi.com/2304-6740/7/5/56/s1, Figures S1-S3: SEM image, TGA curve and DRIFTS spectra of UiO-66-NO ${ }_{2}$.

Author Contributions: Conceptualization, Z.C., T.I. and O.K.F.; methodology, Z.C.; software, Z.C.; validation, T.I. and O.K.F.; formal analysis, X.W., Z.C.; investigation, Z.C. and X.W.; resources, O.K.F.; data curation, Z.C. and X.W.; writing-original draft preparation, Z.C.; writing—-review and editing, X.W., T.I. and O.K.F.; visualization, Z.C. and X.W.; supervision, T.I. and O.K.F.; project administration, Z.C., T.I. and O.K.F.; funding acquisition, O.K.F.

Funding: This research was funded by STIR from ARO, grant number W911NF-18-1-0050.

Acknowledgments: The authors thank Zoha Syed for helpful discussions. This work made use of the EPIC facility of Northwestern University's NUANCE Center, which has received support from the Soft and Hybrid Nanotechnology Experimental (SHyNE) Resource (NSF NNCI-1542205); the MRSEC program (NSF DMR-1720139) at the Materials Research Center; the International Institute for Nanotechnology (IIN); the Keck Foundation; and the State of Illinois, through the IIN. This work made use of the IMSERC at Northwestern University, which has received support from the NSF (CHE-1048773 and DMR0521267); Soft and Hybrid Nanotechnology Experimental (SHyNE) Resource (NSF NNCI-1542205); the State of Illinois and International Institute for Nanotechnology (IIN). X.W. acknowledges support from China Scholarship Council (CSC) during his visit to Northwestern University.

Conflicts of Interest: The authors declare no conflict of interest.

\section{References}

1. Furukawa, H.; Cordova, K.E.; O'Keeffe, M.; Yaghi, O.M. The Chemistry and Applications of Metal-Organic Frameworks. Science 2013, 341, 1230444.

2. Férey, G. Building Units Design and Scale Chemistry. J. Solid State Chem. 2000, 152, 37-48. [CrossRef]

3. Yuan, S.; Feng, L.; Wang, K.; Pang, J.; Bosch, M.; Lollar, C.; Sun, Y.; Qin, J.; Yang, X.; Zhang, P.; et al. Stable Metal-Organic Frameworks: Design, Synthesis, and Applications. Adv. Mater. 2018, 30, 1704303.

4. Horike, S.; Shimomura, S.; Kitagawa, S. Soft porous crystals. Nat. Chem. 2009, 1, 695-704. [CrossRef] [PubMed]

5. Chen, Z.; Hanna, S.L.; Redfern, L.R.; Alezi, D.; Islamoglu, T.; Farha, O.K. Reticular chemistry in the rational synthesis of functional zirconium cluster-based MOFs. Coord. Chem. Rev. 2019, 386, 32-49. [CrossRef]

6. Zhang, X.; Huang, Z.; Ferrandon, M.; Yang, D.; Robison, L.; Li, P.; Wang, T.C.; Delferro, M.; Farha, O.K. Catalytic chemoselective functionalization of methane in a metal-organic framework. Nat. Catal. 2018, 1, 356-362.

7. Zhang, X.; Vermeulen, N.A.; Huang, Z.; Cui, Y.; Liu, J.; Krzyaniak, M.D.; Li, Z.; Noh, H.; Wasielewski, M.R.; Delferro, M.; et al. Effect of Redox "Non-Innocent" Linker on the Catalytic Activity of Copper-CatecholateDecorated Metal-Organic Frameworks. ACS Appl. Mater. Interfaces 2018, 10, 635-641. [CrossRef] [PubMed]

8. Liu, J.; Ye, J.; Li, Z.; Otake, K.-i.; Liao, Y.; Peters, A.W.; Noh, H.; Truhlar, D.G.; Gagliardi, L.; Cramer, C.J.; et al. Beyond the Active Site: Tuning the Activity and Selectivity of a Metal-Organic Framework-Supported Ni Catalyst for Ethylene Dimerization. J. Am. Chem. Soc. 2018, 140, 11174-11178. [CrossRef] [PubMed]

9. Chen, X.; Jiang, H.; Hou, B.; Gong, W.; Liu, Y.; Cui, Y. Boosting Chemical Stability, Catalytic Activity, and Enantioselectivity of Metal-Organic Frameworks for Batch and Flow Reactions. J. Am. Chem. Soc. 2017, 139, 13476-13482. [CrossRef] [PubMed]

10. Chen, Z.; Islamoglu, T.; Farha, O.K. Toward Base Heterogenization: A Zirconium Metal-Organic Framework/ Dendrimer or Polymer Mixture for Rapid Hydrolysis of a Nerve-Agent Simulant. ACS Appl. Nano Mater. 2019, 2, 1005-1008. [CrossRef] 
11. Wang, S.; Chen, Y.; Wang, S.; Li, P.; Mirkin, C.A.; Farha, O.K. DNA-Functionalized Metal-Organic Framework Nanoparticles for Intracellular Delivery of Proteins. J. Am. Chem. Soc. 2019, 141, 2215-2219. [CrossRef]

12. Lian, X.; Fang, Y.; Joseph, E.; Wang, Q.; Li, J.; Banerjee, S.; Lollar, C.; Wang, X.; Zhou, H.-C. Enzyme-MOF (metal-organic framework) composites. Chem. Soc. Rev. 2017, 46, 3386-3401. [CrossRef]

13. Li, G.; Zhao, S.; Zhang, Y.; Tang, Z. Metal-Organic Frameworks Encapsulating Active Nanoparticles as Emerging Composites for Catalysis: Recent Progress and Perspectives. Adv. Mater. 2018, 30, 1800702.

14. Osterrieth, J.W.M.; Wright, D.; Noh, H.; Kung, C.-W.; Vulpe, D.; Li, A.; Park, J.E.; Van Duyne, R.P.; Moghadam, P.Z.; Baumberg, J.J.; et al. Core-Shell Gold Nanorod@Zirconium-Based Metal-Organic Framework Composites as in Situ Size-Selective Raman Probes. J. Am. Chem. Soc. 2019, 141, 3893-3900. [CrossRef]

15. Rieth, A.J.; Yang, S.; Wang, E.N.; Dincă, M. Record Atmospheric Fresh Water Capture and Heat Transfer with a Material Operating at the Water Uptake Reversibility Limit. ACS Cent. Sci. 2017, 3, 668-672. [CrossRef]

16. Kim, H.; Yang, S.; Rao, S.R.; Narayanan, S.; Kapustin, E.A.; Furukawa, H.; Umans, A.S.; Yaghi, O.M.; Wang, E.N. Water harvesting from air with metal-organic frameworks powered by natural sunlight. Science 2017, 356, 430-434. [CrossRef] [PubMed]

17. Furukawa, H.; Gándara, F.; Zhang, Y.-B.; Jiang, J.; Queen, W.L.; Hudson, M.R.; Yaghi, O.M. Water Adsorption in Porous Metal-Organic Frameworks and Related Materials. J. Am. Chem. Soc. 2014, 136, 4369-4381. [CrossRef]

18. Towsif Abtab, S.M.; Alezi, D.; Bhatt, P.M.; Shkurenko, A.; Belmabkhout, Y.; Aggarwal, H.; Weseliński, Ł.J.; Alsadun, N.; Samin, U.; Hedhili, M.N.; et al. Reticular Chemistry in Action: A Hydrolytically Stable MOF Capturing Twice Its Weight in Adsorbed Water. Chem 2018, 4, 94-105. [CrossRef]

19. Chen, Z.; Li, P.; Zhang, X.; Li, P.; Wasson, M.C.; Islamoglu, T.; Stoddart, J.F.; Farha, O.K. Reticular Access to Highly Porous acs-MOFs with Rigid Trigonal Prismatic Linkers for Water Sorption. J. Am. Chem. Soc. 2019, 141, 2900-2905. [CrossRef]

20. Cadiau, A.; Adil, K.; Bhatt, P.M.; Belmabkhout, Y.; Eddaoudi, M. A metal-organic framework-based splitter for separating propylene from propane. Science 2016, 353, 137-140. [CrossRef]

21. Lin, R.-B.; Li, L.; Zhou, H.-L.; Wu, H.; He, C.; Li, S.; Krishna, R.; Li, J.; Zhou, W.; Chen, B. Molecular sieving of ethylene from ethane using a rigid metal-organic framework. Nat. Mater. 2018, 17, 1128-1133. [CrossRef] [PubMed]

22. Cui, X.; Chen, K.; Xing, H.; Yang, Q.; Krishna, R.; Bao, Z.; Wu, H.; Zhou, W.; Dong, X.; Han, Y.; et al. Pore chemistry and size control in hybrid porous materials for acetylene capture from ethylene. Science 2016, 353, 141-144. [CrossRef] [PubMed]

23. Chen, Z.; Adil, K.; Weselinski, L.J.; Belmabkhout, Y.; Eddaoudi, M. A supermolecular building layer approach for gas separation and storage applications: The eea and rtl MOF platforms for $\mathrm{CO}_{2}$ capture and hydrocarbon separation. J. Mater. Chem. A 2015, 3, 6276-6281. [CrossRef]

24. Chen, Z.; Feng, L.; Liu, L.; Bhatt, P.M.; Adil, K.; Emwas, A.-H.; Assen, A.H.; Belmabkhout, Y.; Han, Y.; Eddaoudi, M. Enhanced Separation of Butane Isomers via Defect Control in a Fumarate/Zirconium-Based Metal Organic Framework. Langmuir 2018, 34, 14546-14551. [CrossRef] [PubMed]

25. Belmabkhout, Y.; Pillai, R.S.; Alezi, D.; Shekhah, O.; Bhatt, P.M.; Chen, Z.; Adil, K.; Vaesen, S.; De Weireld, G.; Pang, M.; et al. Metal-organic frameworks to satisfy gas upgrading demands: Fine-tuning the soc-MOF platform for the operative removal of H2S. J. Mater. Chem. A 2017, 5, 3293-3303. [CrossRef]

26. Yaghi, O.M.; O'Keeffe, M.; Ockwig, N.W.; Chae, H.K.; Eddaoudi, M.; Kim, J. Reticular synthesis and the design of new materials. Nature 2003, 423, 705-714. [CrossRef]

27. Rungtaweevoranit, B.; Diercks, C.S.; Kalmutzki, M.J.; Yaghi, O.M. Spiers Memorial Lecture: Progress and prospects of reticular chemistry. Faraday Discuss. 2017, 201, 9-45.

28. Chen, Z.; Weseliński, Ł.J.; Adil, K.; Belmabkhout, Y.; Shkurenko, A.; Jiang, H.; Bhatt, P.M.; Guillerm, V.; Dauzon, E.; Xue, D.-X.; O'Keeffe, M.; et al. Applying the Power of Reticular Chemistry to Finding the Missing alb-MOF Platform Based on the (6,12)-Coordinated Edge-Transitive Net. J. Am. Chem. Soc. 2017, 139, 3265-3274. [CrossRef]

29. Chen, Z.; Jiang, H.; O'Keeffe, M.; Eddaoudi, M. Minimal edge-transitive nets for the design and construction of metal-organic frameworks. Faraday Discuss. 2017, 201, 127-143. [CrossRef]

30. Jiang, H.; Jia, J.; Shkurenko, A.; Chen, Z.; Adil, K.; Belmabkhout, Y.; Weselinski, L.J.; Assen, A.H.; Xue, D.-X.; O'Keeffe, M.; et al. Enriching the Reticular Chemistry Repertoire: Merged Nets Approach for the Rational Design of Intricate Mixed-Linker Metal-Organic Framework Platforms. J. Am. Chem. Soc. 2018, 140, 8858-8867. [CrossRef] 
31. Jeremias, F.; Fröhlich, D.; Janiak, C.; Henninger, S.K. Water and methanol adsorption on MOFs for cycling heat transformation processes. New J. Chem. 2014, 38, 1846-1852. [CrossRef]

32. Wang, S.; Lee, J.S.; Wahiduzzaman, M.; Park, J.; Muschi, M.; Martineau-Corcos, C.; Tissot, A.; Cho, K.H.; Marrot, J.; Shepard, W.; et al. A robust large-pore zirconium carboxylate metal-organic framework for energy-efficient water-sorption-driven refrigeration. Nat. Energy 2018, 3, 985-993. [CrossRef]

33. Akiyama, G.; Matsuda, R.; Sato, H.; Hori, A.; Takata, M.; Kitagawa, S. Effect of functional groups in MIL-101 on water sorption behavior. Microporous Mesoporous Mater. 2012, 157, 89-93. [CrossRef]

34. Cadiau, A.; Belmabkhout, Y.; Adil, K.; Bhatt, P.M.; Pillai, R.S.; Shkurenko, A.; Martineau-Corcos, C.; Maurin, G.; Eddaoudi, M. Hydrolytically stable fluorinated metal-organic frameworks for energy-efficient dehydration. Science 2017, 356, 731-735. [CrossRef]

35. Fathieh, F.; Kalmutzki, M.J.; Kapustin, E.A.; Waller, P.J.; Yang, J.; Yaghi, O.M. Practical water production from desert air. Sci. Adv. 2018, 4, eaat3198. [CrossRef]

36. Chaemchuen, S.; Xiao, X.; Klomkliang, N.; Yusubov, M.S.; Verpoort, F. Tunable Metal-Organic Frameworks for Heat Transformation Applications. Nanomaterials 2018, 8, 661. [CrossRef]

37. De Lange, M.F.; van Velzen, B.L.; Ottevanger, C.P.; Verouden, K.J.F.M.; Lin, L.-C.; Vlugt, T.J.H.; Gascon, J.; Kapteijn, F. Metal-Organic Frameworks in Adsorption-Driven Heat Pumps: The Potential of Alcohols as Working Fluids. Langmuir 2015, 31, 12783-12796. [CrossRef]

38. Liao, P.-Q.; Huang, N.-Y.; Zhang, W.-X.; Zhang, J.-P.; Chen, X.-M. Controlling guest conformation for efficient purification of butadiene. Science 2017, 356, 1193. [CrossRef]

39. Lin, R.; Villacorta Hernandez, B.; Ge, L.; Zhu, Z. Metal organic framework based mixed matrix membranes: An overview on filler/polymer interfaces. J. Mater. Chem. A 2018, 6, 293-312. [CrossRef]

40. Liu, Y.; Chen, Z.; Liu, G.; Belmabkhout, Y.; Adil, K.; Eddaoudi, M.; Koros, W. Conformation-Controlled Molecular Sieving Effects for Membrane-Based Propylene/Propane Separation. Adv. Mater. 2019, 0, 1807513. [CrossRef]

41. Kalmutzki, M.J.; Diercks, C.S.; Yaghi, O.M. Metal-Organic Frameworks for Water Harvesting from Air. Adv. Mater. 2018, 30, e1704304. [CrossRef] [PubMed]

42. Chen, Z.; Wang, X.; Noh, H.; Ayoub, G.; Peterson, G.W.; Buru, C.T.; Islamoglu, T.; Farha, O.K. Scalable, room temperature, and water-based synthesis of functionalized zirconium-based metal-organic frameworks for toxic chemical removal. CrystEngComm 2019, 21, 2409-2415. [CrossRef]

43. Garibay, S.J.; Cohen, S.M. Isoreticular synthesis and modification of frameworks with the UiO-66 topology. Chem. Commun. 2010, 46, 7700-7702. [CrossRef] [PubMed]

44. Cmarik, G.E.; Kim, M.; Cohen, S.M.; Walton, K.S. Tuning the Adsorption Properties of UiO-66 via Ligand Functionalization. Langmuir 2012, 28, 15606-15613. [CrossRef]

45. Rada, Z.H.; Abid, H.R.; Shang, J.; Sun, H.; He, Y.; Webley, P.; Liu, S.; Wang, S. Functionalized UiO-66 by Single and Binary $(\mathrm{OH})_{2}$ and $\mathrm{NO}_{2}$ Groups for Uptake of $\mathrm{CO}_{2}$ and $\mathrm{CH}_{4}$. Ind. Eng. Chem. Res. 2016, 55, 7924-7932. [CrossRef]

46. Cavka, J.H.; Jakobsen, S.; Olsbye, U.; Guillou, N.; Lamberti, C.; Bordiga, S.; Lillerud, K.P. A New Zirconium Inorganic Building Brick Forming Metal Organic Frameworks with Exceptional Stability. J. Am. Chem. Soc. 2008, 130, 13850-13851. [CrossRef]

47. DeStefano, M.R.; Islamoglu, T.; Garibay, S.J.; Hupp, J.T.; Farha, O.K. Room-Temperature Synthesis of UiO-66 and Thermal Modulation of Densities of Defect Sites. Chem. Mater. 2017, 29, 1357-1361. [CrossRef]

48. Katz, M.J.; Mondloch, J.E.; Totten, R.K.; Park, J.K.; Nguyen, S.T.; Farha, O.K.; Hupp, J.T. Simple and Compelling Biomimetic Metal-Organic Framework Catalyst for the Degradation of Nerve Agent Simulants. Angew. Chem. Int. Ed. 2014, 53, 497-501. [CrossRef]

49. Taddei, M.; Wakeham, R.J.; Koutsianos, A.; Andreoli, E.; Barron, A.R. Post-Synthetic Ligand Exchange in Zirconium-Based Metal-Organic Frameworks: Beware of The Defects! Angew. Chem. Int. Ed. 2018, 57, 11706-11710. [CrossRef]

50. Kandiah, M.; Nilsen, M.H.; Usseglio, S.; Jakobsen, S.; Olsbye, U.; Tilset, M.; Larabi, C.; Quadrelli, E.A.; Bonino, F.; Lillerud, K.P. Synthesis and Stability of Tagged UiO-66 Zr-MOFs. Chem. Mater. 2010, 22, 6632-6640. [CrossRef]

51. Howarth, A.J.; Liu, Y.; Li, P.; Li, Z.; Wang, T.C.; Hupp, J.T.; Farha, O.K. Chemical, thermal and mechanical stabilities of metal-organic frameworks. Nat. Rev. Mater. 2016, 1, 15018. [CrossRef] 
52. Wei, R.; Gaggioli, C.A.; Li, G.; Islamoglu, T.; Zhang, Z.; Yu, P.; Farha, O.K.; Cramer, C.J.; Gagliardi, L.; Yang, D.; et al. Tuning the Properties of $\mathrm{Zr}_{6} \mathrm{O}_{8}$ Nodes in the Metal Organic Framework UiO-66 by Selection of Node-Bound Ligands and Linkers. Chem. Mater. 2019, 31, 1655-1663. [CrossRef]

53. Shearer, G.C.; Vitillo, J.G.; Bordiga, S.; Svelle, S.; Olsbye, U.; Lillerud, K.P. Functionalizing the Defects: Postsynthetic Ligand Exchange in the Metal Organic Framework UiO-66. Chem. Mater. 2016, 28, 7190-7193. [CrossRef]

54. Majewski, M.B.; Noh, H.; Islamoglu, T.; Farha, O.K. NanoMOFs: Little crystallites for substantial applications. J. Mater. Chem. A 2018, 6, 7338-7350. [CrossRef]

55. Islamoglu, T.; Ray, D.; Li, P.; Majewski, M.B.; Akpinar, I.; Zhang, X.; Cramer, C.J.; Gagliardi, L.; Farha, O.K. From Transition Metals to Lanthanides to Actinides: Metal-Mediated Tuning of Electronic Properties of Isostructural Metal-Organic Frameworks. Inorg. Chem. 2018, 57, 13246-13251. [CrossRef]

2019 by the authors. Licensee MDPI, Basel, Switzerland. This article is an open access article distributed under the terms and conditions of the Creative Commons Attribution (CC BY) license (http://creativecommons.org/licenses/by/4.0/). 